\title{
Byatt's "possession" of the Victorian cultural reconstruction and reality contrast
}

\author{
Zhou Hong \\ Changsha Medical University, Huanan Changsha 410000
}

\begin{abstract}
Since the 1990s, with the publication of the novel Possession and the Booker Prize, the British contemporary writer AS Byatt has attracted more and more attention from domestic scholars. Her name frequently appears in academic Scholars, from the perspective of post-modern techniques and narrative structures, parody of classical myths and fairy tales, historical narrative strategies, feminist interpretations, and so on, the most of the research results are based on her research achievements. Works in-depth study. One of the two books on the history of narration and history - Byatt's historical multidimensional study of possession also has been published around the works. Narrative, archetypal criticism and feminism, this paper analyzes the heavy historical sense of the novel. Although these studies cover all aspects of Byatt's creation, it is difficult to explore the author's other important works in the creation of skills, language concerns and so on. In another monograph on contemporary British academic fiction research, Song Yifang the Byatt into David. Lodge (David Lodge), Malcolm. Bradbury (Malcolm Bradbury) campus novelist And the analysis of the dual identities of critics and writers, and the anxiety and compromise they have brought to them. It is noteworthy that the author points out Byatt's strong interest in the relationship between language and world, fiction and reality in the postmodernist period and presents it to the reader in the form of a novel. This article will use Byatt's "possession" of Victoria Cultural reconstruction and reality of the point of comparison, the analysis of this phenomenon summed up their own point of view.

Keywords: British novel death theory, historical novels, Victorian cultural reconstruction and reality contrast, Byatt "possession"
\end{abstract}




\section{The rise of Victorian culture and Victorian novels}

The Victorian era of scientific inventions wave surging, Victorian belief in scientific progress, for the industrial revolution is full of optimism and confidence. The emergence of steamship makes transport and trade reached an unprecedented prosperity, extensive rail traffic runs through the north and south. Victorian British society to advocate modesty and courtesy and moral cultivation is known, but also a social science, cultural economy and industry have been great development of the prosperity of the Japanese empire. At that time the United Kingdom in the literature and art to achieve unprecedented prosperity, this period also formed a gender equality and racial equality concept of progress, the community showing a thriving rising situation.

In the Victorian era, the art world presents a glimpse of the stars. At the time of the literary movement schools, including classicalism, romanticism, Impressionist art, neoclassicism, and post-impressionist.

Byatt's creation in the English-speaking countries have gradually been people's attention and concern. Her fifth novel, "possession" in 1990, the British authoritative novel book prize, the same year, won the Irish international novel award. It can be said that her creative career has reached a new peak. This novel has brought great reputation to Byatt, laid her important position in the English literary world and the world literary world, caused worldwide research boom, but also won the media, critics and readers unanimously approved. Byatt's novels include letters, poems, diaries, fairy tales and other narrative material, describing the story of the time span from ancient times to the Victorian era and then to contemporary society, such a huge system called the postmodern classic. With Byatt novels received people's sought after also means that the community set off a upsurge of Victorian novels.

\section{The Victorian era and post-modern historical imagination}

Queen Victoria (Alexandra Victoria, Alexandrina Victoria in 1837, the throne (when she was 18 years old), the reign of 63 years (June 20, 1837 to January 22, 1901), is the United Kingdom The most powerful of the so-called "Sunset" period, during her reign until her death, to the beginning of the First World War in 1914, the British are known as the Victorian era, after 1914, the United Kingdom began to decline.

In the post-modern era, whether history can be recognized, how to be recognized history has always been one of the focus of attention. For the novelists, history is not without end, the end may be only the old narrative or old form; history is not an old and static box waiting to open the past years in the new narrative and new forms Will show a different face. BySat's novel The Possession: A Romance is directed to the great Victorian era with a vision of what is considered "postmodern." The novel does not relate to any real historical figure, but the references to Victorian literary texts and literary figures are very obvious. 
The novel combines the contemporary narrative with the Victorian narrative. The present and the past, the history and the reality, the contemporary academic research and the Victorian literary tradition interweave with each other, the contrast and the interlacing and the interaction, which constitute the fictional world full of tension and charm. The irony and ridiculance of the contemporary academic world is reminiscent of the contemporary image of contemporary scholars in David Lodge's "Small World"; the tracing and parody of the Victorian world of love, bringing the reader back to From the Browning couple to Christina Rossetti, from the Bronte sisters to George Eliot's great Victorian literary tradition. In the second half of the twentieth century, under the academic vision, the romantic stories of vicissitudes in Victorian era were given new moral connotations; and the 19th century marriage and family traditions provided quite interesting reference for contemporary people's emotional life.

"Occupation: A Romance Division" is a novelist literary talent embodies, but also Byatt became the 1990s and even contemporary British novels one of the most important novelists. Her latest novel The Story of a Biographer continues the tradition of contemporary college fiction, as does possession. But objectively speaking, 90's college novels can not be compared with 70,80's achievements, Bradbury's "historical figures", "exchange rate" and Lodge's "small world", "good work" and so on The novel is undoubtedly an insurmountable peak. However, the comedy and satire of the college novels did not disappear in the 1990s novels. In his two novels, "Paradise Message" and "Therapy", Rocky continued to play the comic tradition of British novels, and looked at the modern world of the society in a slightly sarcastic manner. Bradbury in the "Dr. Krimina", let the hero Francis playing with the deconstruction of the theory of fashion, between the lines full of ridicule and irony. Bradbury 's legacy of "reclusive" is a rare masterpiece, it will be an excellent tradition of college novels into the $21 \mathrm{st}$ century. The protagonist is a novelist, is also a narrator of the novel, in 1993, stepping on the 18th century French philosopher Diderot "Enlightenment footprint" to contemporary Russia. In a fascinating and entertaining contemporary tour, Bradbury inserted the story of Cedric Cedarina in Cedar Rizal in Russia two hundred and twenty years ago. 18th century Russian history and the reality of contemporary Russia intertwined, forming a clear and interesting juxtaposition and control.

Historical novels or novels with history as the background and history as references, whether using multiple sounds or using contemporary perspectives, whether by satirical or smudged comedy, are more or less explicitly or implicitly associated with contemporary life Subtle connection, and some novels soaked contemporary people's feelings, values, ethics, meaning and human nature and other modern consciousness. Since the 1990 s, some novels do not use historical and cultural traditions as materials, but the brush strokes deep into the post-Thatcher era British reality, a direct display of the contemporary British people's psychological turmoil and the dilemma. 


\section{Byatt 's "possession" and the postmodern view of history}

The English novel "Possession" (ASByatt, 1936-), a famous contemporary writer, was published in 1990, the most important award in the field of English fiction, the Manbuk Award, Criticism at home and abroad criticism boom. Most of the comments focus on the multiple interpretations of texts in 20th century theories, including feminism, psychoanalysis, archetypal criticism, dialogue theory, structuralism, deconstruction, and narratology.

Postmodernism focuses on the history of the text, diversity, openness and uncertainty and some other features, committed to the deconstruction of the historical description of the grand and past historical argument, to participate in the history of restructuring and interpretation, questioning the history of research The historical basis of the narrative as a rhetorical structure of the language. Hayden White, a postmodernist historian, suggests that historical discourse has three modes of interpretation: formal argumentation, complex arrangement, and ideological implication. He feels that the deeper structure of history is poetic and emphasizes the fiction and imagination of historical texts. Characteristics. The New Historicists broke the boundary between history and literature, believing that history and literature can be "intertextual". From this point of view, history is not only a record of past events, but a rhetorical text that is closely related to the ideology, value judgment and narration of historians. As the nineteenth-century famous historian Frank Ranke regarded as the standard of "truthfully straight book," the historical narrative as a criterion of postmodernism can only be said to be a glorious dream. For, as Foucault puts it, a "singular" history is no longer in existence, and it is replaced by the lowercase plural "history".

Byatt "Possession" This work is not only rich and vivid, contrast to the original ecology of life, but also for the rumination of life, open the reader's mind, deepen the deepening of understanding of life. The novels are the same as her other works. They are rich in content, while other novels use the structure of reasoning novels, which makes suspenseful stories more exciting. These are Byatt's post-modern history of identity and the pursuit of the show.

\section{Byatt "possession" of the Victorian cultural reconstruction and reality contrast}

In Byatt's work, the attention to tradition is also being actively reflected. In her novels and her novels, there is a very conscious historical consciousness and historical complex so that it will not erase the historical truth with its emphasis on poetic and historical imagery. The original features. In the "possession" embodied in the historic nature of the multiple historical space is more intense. Simply display the historical atmosphere or create a historical atmosphere of at most a "past". It embodies the historic combination of historical spirit and contemporary consciousness, historical imagination and reality. It is not only a historical point of view, but also a transcendence of timeliness. 
Byatt "possession" of the sophisticated use of the narrative blank this means to create ups and downs of the suspense to read, while the use of repetitive techniques can make the reader understand the history of the original period. Byatt's attempt to fill the gap in history by making use of the repetition of this narrative, building the historical system of knowledge of the past, expands the scope of our understanding, and makes her narrative more active.

Respect for Realistic Novel Traditions are clearly grounded in fact ... The fictional text of the great tradition is, in fact, the text of the humanistic faith; many novelists now seem to feel that their relationship to these texts is not easy. Therefore, many formal innovations in modern English novels involve only their own and aesthetic aspects.

As the "Victorian and postmodern historical imagination: Byatt" New Victorian novel "research" concerned, try to analyze the filter process itself embodies the cultural criticism, meaning that the Western intellectuals classical human feelings and Byatt 's "Possession" in the pursuit of the Victorian cultural complex when the description of the traditional history by adding the imagination of the color to focus on, but not forgetting And the reality of the control to achieve a just right.

\section{Acknowledgements}

Fund Project: 2015 Hunan Social Science Fund Foreign Language Research Joint Projec. An Anlysis of the Cultural Reconstruction and Reality Contrast of the Neo-Victorian Novel Possession Item Number: 15WLH03

\section{References:}

[1] A.S. Byatt's humanistic reappearance of the Victorian era in "possession" and "angels and insects"

[2] The Return of History - The Historical Narrative Strategy of Byatt's Possession [J]; Journal of Nanjing University of Science and Technology (Social Science Edition); 2005-01 【Co-citations】 Foreign Literature; 2003-01

[3] Cheng Qian ;; History of the cycle - Byatt's novel "possession" of the plot structure prototype $[\mathrm{J}]$; Foreign Literature;

[4] Cheng Qian; Byatt and her magic book "possession" [N]; Chinese reading newspaper; 2003

[5], Cheng Qian; Returning to the History of History - Analysis of Byatt's Possession of Historical Narrative Strategy [J]; Foreign Literature; 2003-01

[6] Cheng Qian; Returning to the History of History - Analysis of Byatt's Possession of Historical Narrative Strategy [J]; Foreign Literature; 2003-01

[7] Hanzhaojing; Byatt's "possession" of ecological feminist interpretation [D]; Liaoning Normal University;

[8] He Fang, "possession" of the narrative strategy [D]; Hebei Normal University; 